\title{
BUNDA: KISAH CINTA 2 KODI BY ASMA NADIA: A STRUCTURALISM STUDY
}

\author{
Suhailee $^{1}$, Ali Imron ${ }^{2}$, Nafron Hasyim ${ }^{3}$, Atiqa Sabardila ${ }^{4}, \&$ Markhamah $^{5}$ \\ ${ }^{1}$ Student of Indonesian Language Education Master's Program, Universitas Muhammadiyah Surakarta \\ 2,3,4,5, Lecturer of Indonesian Language Education Master's Program, Universitas Muhammadiyah Surakarta
}

Corresponding Author: Suhailee Email:Suhaileesohnui2@gmail.com

\begin{tabular}{l}
\hline ARTICLE INFO \\
\hline Received: 14-07-2020 \\
Accepted: 10-10-2020 \\
Published: 12-10-2020 \\
Volume: 4 \\
Issue: 2 \\
DOI: \\
https://doi.org/10.33019/lire.v \\
3i2.87 \\
\hline KEYWORDS \\
\hline
\end{tabular}

ABSTRACT

This study aims to describe the socio-historic background of (1) Asma Nadia and

(2) the structure of Bunda: Kisah Cinta 2 Kodi. This study uses descriptive qualitative method. The research strategy is embedded case studies. The research data are in the form of words, phrases, sentences, and paragraphs in the novel Bunda: Kisah Cinta 2 Kodi that contains information about the socio-historic background of Asma Nadia, and the structure of the novel. The primary data source is the novel and the secondary data source is relevant journal articles. The data were collected through library, observation, and documentation techniques. The data were analyzed using the semiotic reading method, namely heuristic and hermeneutic reading. The results of study are: (1) Sociohistorical setting: Asma

Structural Study; Novel; Nadia was born into a literary family (her grandfather, Teuku Muhammad Usman Socio-history. El Muhammady and her two siblings, Helvy Tiana Rosa and her brother Aeron Tomino, and her husband, Isa Alamsyah, were writers). Her works have particular characteristics: Islamic theme, simple language, and the struggle of Moslem women. (2) The structure of novel: the theme is the struggle of a mother in a family. It uses flashback method, since the story takes regressive plot. The important figures are Kartika, Aryani, Farid, Bagja, Farid's mother, Anton's mother and Siti. The setting: schools, Kartika boarding house, campus canteens, cinemas, bookstores, Aryani's house, hospitals, abortion clinics, Tanah Abang market, Aryani's in-law's house, mushalla, and food stalls. Time setting: 1962, 1963, 1965, 1989, 1992, 1998 and 2000. Social setting: Kartika comes from Javanese and Minangkabau parents, whose works are civil servant and teacher.

\section{INTRODUCTION}

Literary works are social phenomena and products. They reflect a moving social entity with pattern, structure, function, as well as activities and socio-cultural conditions. In other words, the condition becomes the background where the works are written (Fananie, 2002: 193). Ratna (2004: 60) states that literature and society are intertwined. The relationship is due to several reasons. First, literary works are written by authors. Second, authors are members of society. Third, authors utilize the richness of the society. Fourth, the literary works can be used by society.

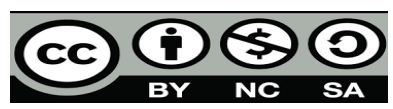

This work is licensed under Creative Commons Attribution-ShareAlike 4.0 Internasional. Copyright (C) 2020, Suhailee, et. al 
Novel tells about various problems faced by human in their interaction with each other and with the environment, adding to their interaction with God (Al Ma'ruf, 2010: 15). Novels grow rapidly in Indonesia, proven by abundant publication of new works. They have varied themes and contents, such as social issues within society.

Ratna (2015: 88) mentions that, etymologically, structure came from the Latin word structura, which means 'form or building'. According to Jean Peaget (in Endaswara, 2013: 50), structuralism contains three main issues. First, a wholeness, which means the parts or the elements are adjusted to a set of intrinsic guidelines determining the whole structure or the parts. Second is transformation, which means it responds to the continuous transformation procedures enabling the formation of new materials. Third is self-regulation, which means that a work does not need external matters to maintain the transformation procedures. The structure is autonomous from other reference.

Novel is one of literary works in the form of fiction, narrative text, or narrative discourse. Fiction means imaginative stories, a narrative story which is different from history or real events (Abrams, 1981; Farida Nugrahani, S. Sri Wahono dan Ali Imron. 2019).

Bunda: Kisah Cinta 2 Kodi written by Asma Nadia tells about the awareness of the main character of the social issues in the complex and complicated aspects of life. The structure is depicted through the main female character, which is the representation of a female personality in facing, addressing, and overcoming her problems. As an author, Asma Nadia wants readers to know the structure of the novel. She is known for her capability in revealing social issues through her works.

Bunda: Kisah Cinta 2 Kodi is a story about Kartika, the main character, who struggles for the life of her household and the whole family, for the hopes, dream, and love of her husband and children. Kartika gains her courage to open a Moslem clothing business, of which she knows nothing about. She strives not only to maintain her family existence, but also to return the family love to her.

This paper will describe the socio-historical background of Asma Nadia and the structure of Bunda: Kisah Cinta 2 Kodi by Asma Nadia. 


\section{METHODOLOGY}

The research employs qualitative descriptive method. The method is not about the level of the research, but the nature, in that the findings are presented in detailed, in-depth, and comprehensive description about why and how particular things happen (Sutopo, 2006: 139).

In general, the design of qualitative research is a case study, which is a strategy to reveal a particular case. The research employs embedded case study design. Here, the limitation is firm and clear because it is different from grounded research. It is not to explore the data, but the limitation or focus is established and made into the research target (Sutopo: 137-139).

A research object means the elements that work together with the research target to form the words and data context (Sudaryanto, 1993: 30). Here, the object under study is the socio-historical aspect of Asma Nadia and the structure of her novel, Bunda: Kisah Cinta 2 Kodi, which is analyzed using structuralism approach. The data are validated using triangulation, a common technique for qualitative research, particularly theoretical triangulation. It is conducted by taking more than one theory in discussing the topic.

The data are analyzed using semiotic reading model: heuristic and hermeneutic. It begins with heuristic reading, where readers can find the linguistic meaning of the work (Abdullah, in Sangidu 2004: 19). Further, hermeneutic reading is carried out, where researcher read the text several times from the beginning to the end to reveal the structuralism elements of the novel.

\section{RESULTS AND DISCUSSION}

\subsection{Socio-History of Asma Nadia}

An author's biography can be used by the readers to understand the origins and the intricacy of the work. The description of Asma Nadia's (the author of the novel Bunda: Kisah Cinta 2 Kodi) socio-historical background includes the biography, the works, social and cultural background, and the characteristics of her works.

Biography: Asma Nadia was born in Jakarta, March 26, 1972. She is an author of novels and short stories, who is also known as the founder of Forum Lingkar Pena and the manager of Asma Nadia Publishing House. She is the second child of Amin Usman, who was from Aceh, and 
Maria Eri Susanti, a Chinese descent mualaf (a person who converts to Islam) from Medan. She has an older sister and a younger brother, Helvy Tiana Rosa and Aeron Tomino, respectively. Three of them dedicate their life to writing, similar to their grandfather, Teuku Muhammad Usman El Muhammady. She married Isa Alamsyah, who is also a writer. From the marriage, they got two children: Eva Maria Putri Salsabila and Adam Putra Firdaus. Both of them also pursue their career in writing.

Works: Asma Nadia has written numerous works and published them almost every year. She published nine works in 2000, five in 2001, four in 2002, and ten in 2004. The number decreased in 2006, 2007, and 2008, five works each. She wrote six other works in 2009. The details of her works in the years after are mentioned below.

In 2010, she published two works: Sakinah Bersamamu and Anggun. In 2011, she wrote seven works: Dendam Positif, Rumah Tanpa Jendela, Twittografi Asma Nadia, New Catatan Hati Seorang Istri, My Tweet-O-Graphy, CInta di Hujung Sajadah, and Ammahige Haj Bayake. In 2012, she wrote three novels: Catatan Hati yang Cemburu, Catatan Hati di Setiap Doaku, and 17 Catatan Hati Ummi (a compilation of three novels and ten short stories during 1995-2011. In 2013, she wrote Assalamualaikum, Beijing; Salon Kepribadian, Jangan Bercerai Bunda, and La Tahzan for Hijabers. In 2014, she wrote Surga yang Tak Dirindukan, Pesantren Impian, and Aisyah Putri: Jilbab in Love. In 2016: Jilbab Traveler: Love Sparks in Korea and Antara Cinta dan Ridha Ummi: Mana yang Kau Pilih. 2017: Bunda: Cinta 2 Kodi, and Bidadari untuk Dewa. In 2018: Dokter yang Dirindukan and Cinta dalam 99 Nama-Mu, and From Me to You: Love Notes.

Social Historical Background: after graduated from SMA 1 Budi Utomo, Jakarta, Asma Nadia continued her study to the Faculty of Agricultural Technology of Bogor Agricultural Institute. She did not finish her study because of an illness. Luckily, she kept on writing, for it is her obsession, when her health condition decreases. Besides, her family's support motivated her to continue writing. Asma Nadia sent her works to Islam magazine. Her short stories, Imut and Koran Gondrong, won the first place of Islamic Short Story Competition (Lomba Menulis Cerita Pendek-LMCPI), a national competition held by Aninda magazine in 1994 and 1995.

Asma Nadia, other than known as a writer and a public speaker, she is also a traveler, as one of her works suggests - A Jilbab Traveler. She has visited more than 51 countries and 206 
cities. In November 2012, she was invited to attend an event named Writers in Residence in Can Serrat, Spain. She travelled to Morocco after visiting Russia, Poland, Greece, Italia, Vienna, and other European cities.

Literary characteristics: in building the stories and characterization, Asma Nadia never presents her characters with exact hue. To her, no human is perfect, either a protagonist or antagonist. Her theme is always related to religion principles. Strong and touching messages are always reflected in her works, such as in Bunda: Kisah Cinta 2 Kodi. The work, which was also made into movie, was inspired from a real incident of a Moslem businesswoman, named Ika Kartika.

Asma Nadia's works are known for their religious values, simple languages, and Moslem women's struggles. Some of her monumental works include Surga yang Tak Dirindukan, Pesantren Impian, and Aisyah Putri: Jilbab in Love. All of them are about Moslem Women.

\subsection{The Structure of Novel Bunda: Kisah Cinta 2 Kodi}

All components of a literary work should form a whole cohesive structure. To analyze one of Asma Nadia's worka, Bunda: Kisah Cinta 2 Kodi, the discussion focuses on the theme, story facts about the characterization, plot, and setting. These components dominate the story and it is also related to the aim of the present study.

\section{Theme}

The novel tells about a mother who has to fulfill the family's need amidst the life difficulties. The theme is commonly found in real life. It is about Kartika, who gives positive messages and inspiration to the readers. Kartika is an idealist, tenacious, and persevering. She is good at painting. Kartika grows without the love of a father. Even so, she learns from her mothers' sorrow and builds her dream out of it. Kartika becomes a mother who never gives up and always works hard to fulfill her needs without abandoning her responsibility as a homekeeper.

"Farid dan Kartika tahu, dalam kondisi sesulit apa pun harus mempertahankan idealisme dan logika, serta tidak mengikuti langkah panik para pemburu dolar yang mencari keuntungan di kesempitan yang ada" (p. 254). 
The quotation represents Kartika's attitude towards the fact that she does not have a father. Besides, she receives different treatment from her siblings because she is female. However, it does not break heart nor stop her hopes and dream, for she has a mom who always supports and gives her power. Her mother is the figure that she admires, leading her to precious lesson in life. Kartika is determined in her work or in other matters.

\section{Story Facts}

Story fact contains plot, character, or characterization and setting (Stanton, 2016: 22). The story facts in Bunda: Kisah Cinta 2 Kodi are as follow.

\section{Plot}

Plot is divided into five stages: situation, generating circumstances, rising action, climax, resolution.

Based on the observation, the plot used in the novel is regressive, which begins with generating circumstances.

\section{1) Generating Circumstances I}

The stage is the introduction of the conflict. It will develop to further conflicts in the next stages. The novel begins with the life of Kartika and Farid after they got married, which is stormed by a problem. The conflict is presented on page 4 to 6 .

“Tidak! Wanita itu tak pernah membayangkan, bahkan dalam impian terburuk sekalipun, mendapat permohonan sedemikian pelik. Seorang lelaki berlutut di depannya, menadahkan maaf dan ampun, untuk sebuah permintaan yang mustahil dipenuhi. Menikah lagi? Bukan, bahkan itu terasa ringan dibanding tuntutan lelaki yang kini menjadi suami. ..." (p. 4-5).

2) Situation

Situation phase is the opening of the story, in which the information about the story serves to underlie the next event. The stage consists of describing and introducing the characterization or the characters. In the novel, the situation begins with the story of Aryani and Bagja (page 8-22). Below are the examples of the situation

"Sikap yang kadang terkesan kasar dan tidak acuh, kini berubah pemurah. Tidak satu hari lewat, tanpa sanjungan untuk calon istri. ..." (p. 16). 
Besides, the situation phase also describes the main character, Kartika, which is on page 24-38, 50-62, 78-82, 92-106, 116-120, 140-163 dan 180-208

\section{3) Generating Circumstances II}

Generating circumstances II is the continuation of Generating Circumstances I. It contains the story of Aryani and Bagja (page 40-48), evident in the following quotation.

"Setiap kesalahan selalu mempunyai akibat dan sebelum dampaknya teratasi, akan menyebabkan efek lanjutan, terkadang berlipat ganda. Seorang yang salah memilih pasangan hidup, baru saja mendapatkan cobaan pertama. Aryani mengira ujian terberat dimulai ketika ..." (p. 40).

In addition, generating circumstances also tells about Kartika and Farid (page 216-250).

4) Rising Action

This is the stage where dramatic events become more intense. Internal conflicts, external conflicts, combination of both, disputes, conflict of interests, and problems are inevitable. The rising action between Aryani and Bagja is written on page 64 to 76 .

"Permintaan yang sulit, namun ibu muda itu sadar Suci butuh banyak perhatian. Ia pun mengundurkan diri. Banyak pihak menyayangkan Aryani, guru yang mendidik dengan hati, pengajar yang jauh lebih kompeten dari suaminya, melepas karier" (p. 71).

Besides, the rising action also tells about Karika and Farid (pp. 252-298).

\section{5) Climax}

Conflicts,, in this stage, are admitted or imposed on the characters. The climax between Aryani and Bagja is represented on page 108-114 and 132-137.

"Aryani harus bangun lebih pagi menyiapkan sarapan suami dan anak-anak. Tidak mudah karena seтиа harus dikalkulasikan. Untuk makan sehari-hari saja, ia perlu memutar otak. Bagaimana dengan anggaran minim mampu mencukupi kebutuhan ...” (p. 108).

The conflict between Kartika and Farid is represented on page 300-334.

6) Resolution

Conflicts that reach the climax is given a resolution. The tense becomes looser. Other conflicts, the sub-conflicts, or additional conflicts (if any) are given some ways out, ending the 
story. The resolution between Aryani and Bagja is given on page 210-214, reflected on the following quotation

"Seluruh anggota keluarga duduk mengelilingi meja makan. Raut perempuan yang melahirkan anak-anaknya ke dunia terlihat tanpa riak. Kalimatnya pun teratur. Namun permintaan yang diajukan membuat setiap orang terbelalak. Mama menuntut cerai. Tak hanya Kartika dan dua kakak terkejut. ...” (p. 213).

Another resolution, which is between Kartika and Farid, is given on page 336-356, with the following evident.

"Keduanya lalu membahas secara serius peran mereka sebagai orang tua. Bagaimana Kartika bisa tetap hadir di sisi anak-anak, terlepas kesibukan. Tidak mudah memang bagi muslimah yang telah berkeluarga merintis usaha secara serius. ...” (p. 317).

\section{Characters or Characterization}

\section{Kartika}

Kartika is the main character, a round and dynamic character because she is related to other characters in the novel, as shown in the following quotation

"Begitu juga dengan anak perempuan mereka lahir tak sampai dua tahun kemudian. Wajah dengan pipi ranum menggemaskan...?" (p. 76).

2. Aryani

Aryani is an additional character, a protagonist and flat character because she is the second main character after Kartika.

“Aryani tersentuh melihat keras perjuangan si bungsu bersama suami. Ia memberikan sebuah selendang batik yang bisa dipakai menggendong cucu. Pakai ini. Untuk? Untuk mengikat. Jawaban singkat yang disampaikan sambil mengelus kepala putrinya. ... bahkan sepasang suami istri agar semakin harmonis" (pp. 267-268).

\section{Farid}

Farid is simple and round character because he only has one particular personality and the one of which the aspects of life are told in the story from several possibilities. 
"Farid sama sekali bukan lelaki yang dekat dengan Kartika. Pertemuan pertama justru dimulai dengan keributan menjelang ujian semester..." (p. 34).

4. Bagja

Bagja is an additional character, an antagonist and dynamic type because he has rude and changing characterization, taking a large portion in the story.

"Bagja pulang sedikit terlambat. Menemukan seluruh tubuh putri pertamanya sudah tertutup kain putih kecuali bagian wajah, lelaki itu tidak dapat menyembunyikan kesedihan. .." (p. 136).

\section{Anton}

Anton is an additional character. He has small portion in the story and is not necessary unless his scene is related to the main character, directly or indirectly, as shown in the following quotation.

"Seperti biasa, Anton punya cara unik untuk menyampaikan perasaan, mungkin lebih tepatnya sebuah kegilaan yang tak sembarang orang mau melakukan. Sesama mahasiswa sungkan menegur. Dia mahasiswa S2 lebih senior ...” (p. 26).

6. Deni

Deni is also an additional character, similar to Anton.

"Sekalipun beda kampus, dia selalu mencari cara untuk menolong Kartika menyelesaikan tugas kuliah atau aktivitas kemahasiswaan. Mojang pujaannya aktif dalam berbagai kegiatan dan Deni selalu menyempatkan diri membantu, atau ...” (p. 29).

7. Farid's mother

Farid's mother is a dynamic character because she is told to change and develop her character along with the development of the events and the plot of the story.

"Sejak hari itu Farid hampir tidak pernah pulang. Rumah yang dalam imajinasi Kartika seharusnya bertabur cinta dan kehangatan, menjelma dingin dan senyap. Tapi ia harus mengerti..." (p. 216).

8. Siti

Siti is an dditional character, similar to Anton and Deni 
"Tapi diantara semua pengalaman, pertemuan dengan Bu Siti merupakan momen pembelajaran paling berharga. ..." (p. 160).

\section{Setting}

(1) Setting of Place

Bunda: Kisah Cinta 2 Kodi takes place in several places: (a) at the schoolyard where Bagja has a conflict with Hidayat; (b) Kartika's kos; (c) Campus canteen where Kartika and Anton has lunch; (d) Movie theatre, where Farid and a girl see a poster; (e) bookstore, the favorite place of Farid and the girl, where they can spend hours exploring the shelves; (f) Aryani's house ('Pagipagi sekali Mak Ijah mampir ke rumah Aryani” (p.64); (g) Cipto Mangunkusumo Hospitals, where Suci is hospitalized (p.73) (h) office where Kartika works (p.143); abortion clinic 'Suasana di klinik aborsi di mata Kartika jauh berbeda dengan pelayanna kesehatan pada umumnya....' (p.235); (j) Tanah Abang market, 'saya beli pakaian dari Tanah Abang...' (p.160); (k) Gold jewelry shop 'Aryani mengikuti langkah suami hingga berhenti di depan sebuak toko emas ... 'pilihkan gelang untuk anak kita,' kata Bagja”. (p/75); (1) Aryani’s in-law's house, “Tiba di rumah ipar, keluarga besar sudah berkumpul..." (p.122); (m) Mushola "Kartika hanya meninggalkan putrinya di waktu sholat (p.308); and (n) eatery, "Enak sekali jadi Ilham, ujar Kartika mendengar Farid bercerita di sela-sela suapan nasi lalapan, di warung makan..." (p.100).

2) Setting of time

An author does not usually directly tells the readers when a particular event occur. Instead, he will present it explicitly, relating it to the social event occurred at the same time. The novel takes place from 1962 to 2000, or 38 years.

The time when the story takes place includes: (a) in the morning, 'Pagi-pagi sekali Mak Ijah mampir ke rumah Aryani." (p.64); (b) Afternoon, "Sepanjang siang, deret pekerjaan rumah tangga sudah menanti." (p.109); (c) evening, "Sore itu di bawah curah hujan, Aryani pulang menyusuri tanah becek. ...” (p.41); (d) Night, “Tengah malam, sebuah mobil Colt bak terbuka berhenti di depan deretan rumah kos sederhana ..." (p.26); (e) at two and three in the afternoon' (f) at four in the morning; (g) in 1962, when Aryani met Bagja; (h) in 1989, where Kartika, being a student, starts to think about a would-be husband; (j) in 1963), the early life of Aryani and Bagja 
marriage life. This is when Aryani does not expect of her husband's change of attitude, of which she thinks it will be temporary. (k) in 1965, when happiness and sadness collide. Bagja is happy because he officially works as civil servant and when his children are born; (1) in 1992) the phase when Kartika graduates and attains her bachelor degree, hoping that she will get a suitable job; (m) in 1998), when the monetary crisis attacks most countries in Asia Pacific, including Indonesia. Kartika and Farid are married (n) in 2000, when Kartika and Farid receive the hardwork in doing the business.

\section{Social Setting}

Social setting is related to the social environment in the story. In the novel, the social setting is the life of a civil servant, particularly a teacher. The life of a teacher is represented in the quotation "Di sekolah, hari terasa panjang bagi Aryani. Setiap menit ia memandang jarum jam yang seakan tidak bergerak. Tak sabar terbang ke rumah. ..." (pp 133-134), while the civil servant in "Pujian pertama dari sang ayah. Mungkin Papa ingat jerih payah dan paham proses yang dilalui untuk menjadi pegawai negeri." (p.141).

\section{CONCLUSION}

The analysis on Bunda: Kisah Cinta 2 Kodi by Asma Nadia has several findings. It can be concluded that Asma Nadia was born into a literary family (her grandfather and her two siblings are writers). Her works are of a particular nature, such as Islamic themes, simple language style, and involving Moslem women.

The theme of the novel is a mother's struggle for her family. The story facts include flashback which begins with generating circumstances. The main character is Kartika and other characters are Aryani, Bagja, Farid, Anton, Deni, Farid's mother, Anton's mother, and Ibu Siti. The settings are school, Kartika's boarding house (like student apartment), campus canteen, movie theatre, bookstore, Aryani's house, hospital, office, abortion clinic, Tanah Abang market, gold jewelry shop, eatery, Aryani's in-law's house, and musholla. The story takes place within 38 years, from 1962 to 2000. It is told that the character has good social background because her parents work as civil servant and teacher. 


\section{ABOUT THE AUTHOR}

Suhailee Sohnui is a student from Thailand who is pursuing postgraduate studies in the postgraduate program of Masters in Indonesian Language Education, Universitas Muhammadiyah Surakarta.

\section{REFERENCES}

[1] Al- Ma'ruf, Ali Imron. 2010. Kajian Stilistika: Perspektif Kritik Holistik. Surakarta: UNS Pres

[2] Endraswara, Suwardi. 2003. Metode Penelitian Sastra. Yogyakarta: Pustaka Widyatama.

[3] Fananie, Zainuddin. 2002. Telaah Sastra. Surakarta: Muhammadiyah University Press.

[4] Farida Nugrahani, S. Sri Wahono dan Ali Imron. 2019. "Ecranisation of Laskar Pelangi Novel and its Function as Educative Media (Study of Literature Reception)". Humanities \& Social Sciences Reviews eISSN: 2395-6518, Vol 7, No 3, 2019.

[5] Nadia, Asma. 2017. Bunda: Kisah Cinta 2 Kodi. Depok: Asma Nadia Publishing House.

[6] Ratna, Nyoman Kutha. 2004. Teori, Metode, dan Teknik Penelitian Sastra (Dari Strukturalisme Hingga Postrukturalisme, Perspektif Wacana Naratif). Yogyakarta: Pustaka Pelajar.

[7] Ratna, Nyoman Kutha. 2015. Teori, Metode, dan Teknik Penelitian Sastra. Cetakan XIII. Yogyakarta: Pustaka Pelajar.

[8] Rahmanto, B. 1988. Metode Pengajaran Sastra. Yogyakarta: Kanisius.

[9] Sangidu. 2004. Metode Penelitian Sastra, Pendekatan Teori, Metode dan Kiat. Yogyakarta: UGM.

[10] Stanton, Robert. 2012. Teori Fiksi Robert Stanton (Terjemahan Sugihastuti dan Rosi Abi Al Irsyad). Cetakan II. Yogyakarta: Pustaka Pelajar 
[11] Sudaryanto. 1993. Metode dan Aneka Teknik Analisis Bahasa (Pengantar Penelitian Wahana Kebudayaan Secara Linguistis). Yogyakarta: Duta Wacana University Press.

[12] Sutopo. 2006. Metodologi Penelitian Kualitatif. Surakarta: UNS. 